Article

\title{
How Corporate Social Responsibility Influences Business Model Innovation: The Mediating Role of Organizational Legitimacy
}

\author{
Baoliang Hu ${ }^{1}$, Tao Zhang ${ }^{2, *}$ and Shuai Yan ${ }^{1}$ \\ 1 School of Management, Hangzhou Dianzi University, Hangzhou 310018, China; bhu@hdu.edu.cn (B.H.); \\ yanshuai1221@163.com (S.Y.) \\ 2 Faculty of International Tourism and Management, City University of Macau, Macau 999078, China \\ * Correspondence: tzhang@cityu.mo
}

Received: 5 March 2020; Accepted: 24 March 2020; Published: 28 March 2020

check for updates

\begin{abstract}
Business model (BM) innovation driven by corporate social responsibility (CSR) has attracted considerable attention from scholars. However, the understanding of whether and how CSR influences BM innovation is limited. Therefore, this paper aimed to fill these gaps by exploring the influence of CSR on BM innovation through the mediating role of organizational legitimacy (OL). This paper proposed research hypotheses on the relationships among CSR, OL, and BM innovation and empirically tested these hypotheses by using the hierarchical regression analysis method with data collected from 186 firms. The results of this study show that both CSR and OL positively influence BM innovation. The results also show that CSR positively influences OL and OL mediates the relationship between CSR and BM innovation. This paper provides new insights into the relationship between CSR and BM innovation by answering questions of whether and how CSR influences BM innovation. This paper may help managers better understand how to link CSR and BM innovation.
\end{abstract}

Keywords: corporate social responsibility; organizational legitimacy; business model; business model innovation

\section{Introduction}

Since the mid-1990s, with the rapid development of technology (especially Internet technology), the business model (BM) concept has become prevalent [1]. BM is not only an activity system that is designed to help firms create, deliver, and capture value through the exploitation of business opportunities [2], but is also an organizational configuration that is used by firms to differentiate themselves from competitors and create competitive advantages [3]; it is thus an important factor in improving firm performance [4-6].

However, due to the change in environment and imitation of competitors, the initial BM of a firm, no matter how novel and competitive it may be, will become inefficient and outdated $[7,8]$. Firms thus need to innovate their BMs to meet the challenges of environmental change and competitive imitation. Particularly for successful firms, if they do not keep their BMs adapted to environmental change, they run a great risk of failure [9]. Therefore, BM innovation has become a crucial factor for sustaining firm performance and an important source of sustainable competitive advantage $[6,10,11]$.

Given the beneficial outcomes of BM innovation, researchers have focused on identifying its antecedents [12-14]. Some research has linked organizational internal factors to BM innovation [11]. For example, organizational learning [14,15], dynamic capabilities [16], managerial cognitions [13,17], and corporate entrepreneurship [18] have been shown to lead to BM innovation. Other research has explored the influence of organizational external factors on BM innovation [11]. For example, the demands of stakeholders [19,20], regulatory forces [21], opportunities brought about by new 
technologies [18,22], and environmental dynamism and munificence [5] have been shown to function as drivers of BM innovation. While the literature has provided valuable findings, gaps still exist. For example, research on this issue has identified a limited number of antecedents [23], and scholars are still needed to find new antecedents [13]. The reason is that antecedents of BM innovation "may be many, different in nature, and placed at different levels" [11] (p. 217). Gaps also include the limited studies that "systematically theorize the antecedents of BM innovation" [11] (p. 211), and there is a lack of discussion on the process of antecedents influencing BM innovation, resulting in a limited understanding of how to implement BM innovation.

Recent research has begun to emphasize BM innovation driven by corporate social responsibility (CSR). Some studies have found that proactive CSR policies will cause pioneering established companies to innovate their BMs toward social BMs [24-26]. Other studies have demonstrated that CSR activities that respond to greater sustainability, such as facilitating inclusive growth and targeting low-income consumers, can achieve significant BM innovation [27-29]. In conclusion, these studies emphasized that CSR is an antecedent of BM innovation and advocate incorporation of CSR into firms' BMs [25,28]. However, the situation in practice is as follows "companies have in recent years increased their public rhetoric on CSR, the degree to which they actually implement CSR principles in their on-the-ground operations is questionable" [30] (p. 179). This contradiction between rhetoric and reality is "attributable to the fact that these companies have not fully integrated CSR into their business models" [30] (p. 179). If incorporating CSR into BMs is used as the criterion, there are at least three gaps in the literature.

First, few studies have paid attention to the innovation of purely commercial or for-profit BM when analyzing the role of CSR as an antecedent. The existing literature has focused on the effect of CSR on innovating BMs towards social or sustainable BMs [25,27]. They are primarily oriented toward resolving social and environmental issues and are significantly different from purely commercial or for-profit BMs primarily oriented toward profit generation [26,28]. However, almost all firms are concerned with purely commercial or for-profit BMs rather than social or sustainable BMs, because their main motivations are to make profits [6,31]. Therefore, the existing literature is unable to provide an answer of whether firms are interested in incorporating CSR into their BMs.

Second, there is little understanding of whether CSR influences BM innovation positively due to limited research on the theoretical and empirical link between CSR and BM innovation. Although the existing literature has shown that CSR may lead to BM innovation [24,28], these studies are descriptive and inductive rather than theoretical and confirmatory. In addition, little empirical research has been implemented on the influence of CSR on BM innovation. Therefore, the existing literature is unable to provide an answer regarding whether it is really necessary for firms to incorporate CSR into their BMs.

Third, an understanding of how CSR influences BM innovation is lacking because the examination of the process mechanism underlying the link between CSR and BM innovation has been neglected. The existing literature has mainly discussed the direct influence of CSR on BM innovation [28,32], resulting in managers' limited understanding of how to innovate their BMs based on CSR. Therefore, the existing literature is unable to provide an answer to the question of how firms incorporate CSR into their BMs.

This paper sought to fill these gaps. First, this paper sought to analyze the role of CSR as an antecedent of the innovation of the purely commercial or for-profit BM. Unlike the existing literature, which focused on the role of CSR as an antecedent of the innovation of the social or sustainable BM, this study focused on the role of CSR as an antecedent of the innovation of the purely commercial or for-profit BM, because most firms' BMs are primarily oriented toward profit generation. The essence of a purely commercial or for-profit BM (hereafter called BM) is "in defining the manner by which the enterprise delivers value to customers, entices customers to pay for value, and converts those payments to profit" [6] (p. 172), answering "the fundamental questions every manager must ask: How do we make money in this business" [33] (p. 3). Second, this paper sought to check the relationship between CSR and BM innovation. The focuses of this research were elucidation of the effect of CSR on BM innovation and testing it using an empirical research. Third, this paper sought to explore the process 
mechanism by which CSR influences BM innovation by examining the mediating role of organizational legitimacy (OL). Scholars argue that an important way for firms to benefit from CSR is by linking CSR to OL [34,35]. OL is a generalized perception or assumption [36], reflects the response and catering of organizational behaviors to institutional logics and social norms $[37,38]$, and helps firms acquire and utilize resources from stakeholders [37,39], which in turn can promote BM innovation. Therefore, this study highlights the importance of studying OL as a potential mediator of the relationship between CSR and BM innovation.

The contents of this paper are organized as follows. Section 2 briefly reviews the relevant literature and derives hypotheses regarding relationships among CSR, OL, and BM innovation. Section 3 describes the research methodology. Section 4 presents the processes and results of the empirical analysis. Section 5 discusses the findings, theoretical contributions, practical implications, limitations, and further research.

\section{Literature Review and Hypotheses Development}

\subsection{BM Innovation}

In recent years, the BM has become a key concept for understanding how firms realize their value proposition and generate profits. It has therefore attracted considerable attention among scholars in various fields, such as business strategy [6,40], technological innovation [41,42], entrepreneurship management [3,18], and international business [21,43]. Although a consistent view about the definition of a BM has not yet developed, it is generally argued that the essence of a BM is value creation, delivery, and capture [44,45]. For example, Teece described a BM as "the design or architecture of the value creation, delivery, and capture mechanisms" [6] (p. 172). Shafer et al. defined a BM as "a representation of a firm's underlying core logic and strategic choices for creating and capturing value within a value network" [46] (p. 202). Osterwalder and Pigneur defined a BM as "the rationale of how an organization creates, delivers, and captures value" [47] (p. 14).

$\mathrm{BM}$ innovation is an important topic in BM research [18]. It not only helps firms reach new customers and establish relationships with them to obtain a first-mover advantage, but also helps firms establish dynamic advantages that are difficult for competitors to imitate in a dynamic business environment [48,49]. As a result, an increasing number of scholars are beginning to move away from explaining and conceptualizing BMs to exploring and discussing BM innovation [8]. BM innovation refers to "the search for new logics of the firm and new ways to create and capture value for its stakeholders; it focuses primarily on finding new ways to generate revenues and define value propositions for customers, suppliers, and partners" [48] (p. 464). BM innovation can be an act of adjusting an existing BM, or it can be an act of creating a new BM $[23,49,50]$.

\subsection{CSR and BM Innovation}

CSR is a major concept in management literature [51,52]. CSR is a firm's moral and business obligation [53]. Scholars have given a variety of CSR definitions [54-56]. Among them, McWilliams and Siegel's definition is widely adopted $[57,58]$. They defined CSR as "actions that appear to further some social good, beyond the interests of the firm and that which is required by law" [55] (p. 117). Carroll proposed that CSR includes corporate economic, legal, ethical, and discretionary initiatives [54]. While Carroll's framework is widely supported, this paper adopted the stakeholder approach to understand CSR, due to the fact that this approach is useful to understand CSR in almost any context [59]. Applying this approach, scholars have identified several CSR initiatives: customers, employees, shareholders, society, and the environment [60-62].

First, CSR can lead to BM innovation due to its effects on adjusting the existing value proposition and creation. Socially responsible firms will take actions, such as strengthening and expanding the social attributes of products and value activities, to respond to the social concerns of stakeholder groups [55,63], resulting in firms adjusting their existing value proposition and creation. For example, 
McWilliams and Siegel showed that firms engage in CSR for customers, not only leading to developing the product with socially responsible attributes, such as pesticide-free ingredients, but also leading to CSR-related processes, such as the use of organic methods [55]. In addition, firms' responses to the social concerns of stakeholder groups will gain reputations for them [34], which in turn help them attract and motivate stakeholders to participate in adjusting their existing value proposition and creation [55]. For example, Kim et al. showed that employees in socially responsible firms are more likely to be happy and proud of being members of the reputable firm, resulting in deep involvement in the organization and voluntary behaviors beyond job requirements [64].

Second, CSR can lead to BM innovation due to its effects on new business opportunities and new business strategies. Human development obstacles such as climate change and resource scarcity have accelerated the decline of traditional industries and promoted the emergence of new industries. Firms engaged in CSR can respond to these obstacles and thus obtain new business opportunities, which will drive them to abandon the old BMs and develop new BMs suitable for the new industrial characteristics [65]. For example, unlike the manufacturing-based BMs of traditional automobile firms, electric automobile firms have built different kinds of leasing-based new BMs to reduce the battery cost to end users [63]. For the other firms, although they are not in the dying industries, they may need to take actions to cope with changes in business strategies caused by stakeholders' new social concerns [65], which will lead to firms abandoning the old BMs and developing new BMs suitable for the new business strategies. For example, as consumers increasingly focus on energy services rather than energy products, some firms in the energy sector have actively changed their business strategies and in turn built new BMs focusing on providing services [66].

Third, CSR can lead to BM innovation due to its effects on CEO risk-taking incentives. The CEO's cognition determines the new value logic and then the new BM [6]. In addition, the implementation of BM innovation is inseparable from the support and leadership of the CEO [67]. In other words, CEO risk-taking attitude and behaviors are crucial to BM innovation. CSR encourages CEO risk-taking because CSR has a positive effect on CEO risk-taking incentives [68]. In their research on CSR and CEO risk-taking initiatives, Dunbar, $\mathrm{Li}$, and Shi showed that firms possessing an insurance-like benefit due to higher CSR standing would have more risk-taking capacity going forward, and therefore respond by offering CEOs compensation contracts with features that encourage risk taking [68]. Therefore, we proposed the first hypothesis as follows.

H1. CSR has a positive effect on BM innovation.

\subsection{CSR and $O L$}

With stakeholders significantly redefining the role of business in society, OL has become an important issue [38]. Society is increasingly demanding that firms have legitimacy not only in their economic behaviors but also in their social and environmental behaviors [36,38]. OL refers to "a generalized perception or assumption that the actions of an entity are desirable, proper, or appropriate within some socially constructed system of norms, values, beliefs, and definitions" [36] (p. 574). OL is critical to organizational survival $[37,38]$. By enhancing legitimacy, firms can gain stakeholders' recognition, which can be transformed into survival, growth, and sustainability [35]. On the other hand, those firms with weak legitimacy will encounter risks [38]. The value of legitimacy to an organization is also reflected in its contributions to employee dedication [35], customer decision-making [69], investor behavior [70], technological innovation [39], entrepreneurship [71], supply chain [72], and international mergers and acquisitions [73].

Firms can take actions, such as CSR activities, to acquire, maintain, and enhance legitimacy [36,38, 69]. CSR can influence OL for the following reasons. Firstly, the intentions of CSR emphasize that it is a way of gaining OL [74]. Firms engage in CSR in order to enhance the appropriateness of their actions within a set of specific rules, norms, values, and beliefs established by multiple stakeholders [36]. In other words, one of the main intentions of CSR is to pursue public perception or assumption, that is, OL [34]. Secondly, the function of CSR indicates that it can positively influence OL [35]. The consistency 
between firm behaviors and stakeholders' expectations is an important prerequisite for OL [38,75]. CSR contains the positive and responsible commitments and behaviors of firms to stakeholders [35]. Therefore, CSR can meet the expectations of stakeholders and in turn establish, maintain, and enhance OL [38]. For example, Zhao showed that in both developed and developing countries, society has a common understanding that firms are members of society and therefore have responsibilities to make positive contributions to better social development [76]. Therefore, firms carrying out CSR activities can gain social recognition, and thus legitimacy. Thirdly, CSR can help firms cope with legitimacy dilemmas [69]. Controversial firms such as alcoholic beverage producers are more likely to face legitimacy dilemmas due to negative impacts of their products on health [77]. CSR may help offset the negative image generated by controversial products [69]. Finally, some empirical studies have shown that CSR helps to enhance OL [35,78]. For example, an empirical study based on 288 firms conducted by Zheng et al. showed that CSR helps to improve external and internal legitimacy [35]. Therefore, we proposed the second hypothesis as follows.

H2. CSR has a positive effect on OL.

\section{4. $O L$ and BM Innovation}

Resource-based view (RBV) helps to understand BM from both static and dynamic perspectives [79]. From a static perspective, the resource, such as physical and intellectual assets, is one of the components of a BM because it is the basis for value creation, delivery, and capture, and in turn, is required to make a BM work [47,80]. From a dynamic perspective, BM innovation can't be implemented without resource acquisition and allocation [3]. For example, Hamel emphasized that firms must acquire resources concomitantly to the implementation of new BMs [81]. Foss and Saebi suggested that successful implementation of BM innovation may require corresponding changes in the organizational design, such as the setting of objectives and the allocation of resources [11].

OL can promote BM innovation due to its effects on resource acquisition and allocation. OL includes external and internal legitimacy [35]. External legitimacy refers to "the degree to which a firm achieves approval of its actions with outsider stakeholders such as customers, partners, and non-government organizations", and internal legitimacy refers to "the extent to which employees perceive the firm's mission and operations as appropriate" [35] (p. 392). As BM innovation increasingly depends on external resources and capabilities, building good relationships with external stakeholders becomes imperative $[10,82]$. External legitimacy enables firms to obtain trust and reliability from external stakeholders and thus enables firms to build good relationships with them [83]. Accordingly, external legitimacy helps firms acquire external resources, such as financial resources and technology [37,39], and in turn, promotes BM innovation. On the other hand, BM innovation needs firms to reduce employee resistance and improve employee commitment and participation, because employees determine the efficiency of resource allocation and use in BM innovation [9,11]. Internal legitimacy can enhance employee dedication, satisfaction, and cohesion due to the fact that it improves employee trust and recognition $[35,84]$, which can in turn lead to greater efficiency of resource allocation and use in BM innovation.

OL itself is a necessary resource for BM innovation. OL, a social judgment of appropriateness and desirability from stakeholders, is a resource "at least as important as other resources, such as capital, technology, personnel, customer goodwill, and networks" [37] (p. 414), because it is equivalent to the approval, recognition, and acceptance of stakeholders [36,85]. A new BM may encounter legitimacy problems because stakeholders are unfamiliar with it. Stakeholders can't judge whether the attributes of value proposition and creation embodied in this new BM are desirable, proper, or appropriate. As a result, the new BM is difficult to recognize and accept. If the new BM is built by a firm with OL, stakeholders may approve of and accept it [83], because stakeholders are willing to believe that this firm's attributes of value proposition and creation are very likely to be desirable, proper, or appropriate. Therefore, we propose the third hypothesis as follows. 
H3. OL has a positive effect on BM innovation.

\subsection{Mediating Role of $\mathrm{OL}$}

Following the clues provided by relationships mentioned above, we explored whether OL can play a mediating role in CSR influencing BM innovation.

First, we predicted that OL can mediate the relationship between CSR and BM innovation based on the clues provided by the relationship between CSR and OL. As shown in Section 2.3, CSR influences OL. Obviously, firms will be concerned with the beneficial outcomes of CSR influencing OL. One of consequences of OL is its resource effects, not only because it is a resource in itself $[36,85]$, but also because it can help firms acquire resources from external stakeholders [37,39]. Accordingly, when firms connect CSR to OL, they can obtain the resource effects of OL, which in turn can be used to adjust their existing BMs as well as create new BMs for them. Therefore, we argued that OL can play a mediating role in the influence of CSR on BM innovation.

Second, we predicted that OL can mediate the relationship between CSR and BM innovation based on the clues provided by the relationship between OL and BM innovation. As shown in Section 2.4, OL influences BM innovation. Firms will be concerned with the drivers of OL influencing $\mathrm{BM}$ innovation. One of antecedents of OL is CSR, due to the fact that it contains the positive and responsible commitments and behaviors of firms to stakeholders and in turn meets the expectations of stakeholders $[35,36,38]$. Accordingly, CSR can become a driver of OL influencing BM innovation, thus indicating that OL can play a mediating role in the influence of CSR on BM innovation. Therefore, we propose the fourth hypothesis as follows.

H4. OL mediates the relationship between CSR and BM innovation.

The four hypotheses proposed above constitute the conceptual model linking CSR, OL, and BM innovation (see Figure 1).

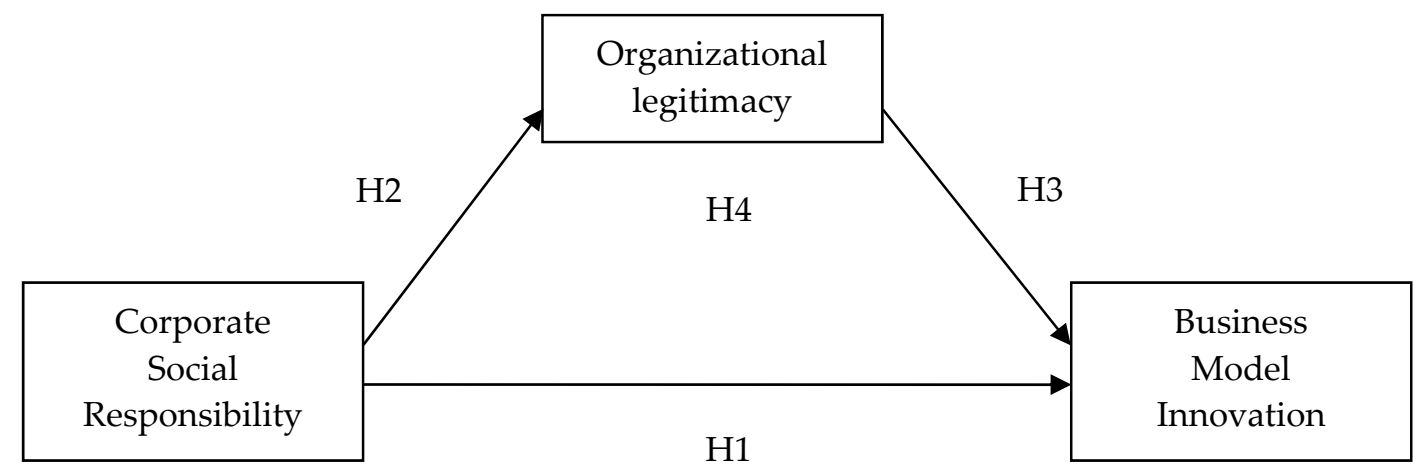

Figure 1. Conceptual model. Note: H4 represents the hypothesis of mediation effect.

\section{Research Method}

\subsection{Sampling and Data Collection}

A questionnaire survey is appropriate for collecting data, especially when secondary data are not available [85]. Due to the fact that there is no mature database such as KLD in China, previous studies choosing Chinese firms as the sample have widely used the survey approach to collect the data related to CSR [60,62], OL [86,87], and BM innovation $[88,89]$. Following these studies, we used questionnaire survey to collect data.

The questionnaire survey was conducted in 2018. We chose firms from Zhejiang province in China as the sample. Zhejiang province is one of the most developed regions in China. The main characteristics of firms in Zhejiang province are of innovativeness and growth orientation, which are in line with the strategic focus of China's economy, and in turn, make these firms representative firms in China. Therefore, firms in Zhejiang province actively engage in CSR and implement BM innovation 
for growth. In addition, due the focus on specialization strategies, BM innovation of Zhejiang firms is less complex and thus easier to measure. Following previous studies [4,90], we collected data from different industries (e.g., chemical and pharmaceutical, textile and clothing, Internet and IT, wholesale and retail, and other industries) to construct a representative sample.

We chose participating firms and respondents with the following criteria. Firstly, the firms selected should not be state-owned holding firms. Generally speaking, state-owned holding firms in China show higher level of CSR and OL than what they should show, and show lower level of BM innovation than what they should show. Therefore, the participating firms should not include state-owned holding firms. Secondly, senior managers, such as general managers, marketing managers, and office directors, were chosen as respondents, because these managers possessed enough information and knowledge to evaluate their respective organizations [91], including their CSR, OL, and BM innovation.

Before the questionnaire was issued, we invited three scholars to evaluate the questionnaire and selected five firms for pretesting. This not only helped us to ensure that the items were suitable for Chinese firms but also helped us to confirm that the respondents we had chosen were sufficiently knowledgeable to complete the questionnaire. The feedback mainly concentrated on the measurement for BM innovation and OL. First, the three scholars suggested that items for BM innovation should focus on changes in components of the BM rather than the continuum between exploiting existing $\mathrm{BM}$ and exploring new BM argued by Pedersen et al. [92]. This study adopted the suggestion because exploiting existing BM and exploring new BM are two different kinds of behaviors that can be performed simultaneously, rather than two ends of a continuum, according to the perspective of organizational ambidexterity [93]. In addition, there is a low correlation between exploiting existing $\mathrm{BM}$ and BM innovation, because exploiting existing BM aims to improve efficiency rather than novelty. Second, five firms suggested that this study should adopt 7-point Likert-type scale rather than the 10-point Likert-type scale argued by Pedersen et al. when measuring BM innovation [92]. They gave the response that the 10-point scale not only increased the difficulty of the respondents' judgment but also was inconsistent with the 7-point scale of other variables in the questionnaire. This study agreed with them and adopted their suggestions. Third, service firms in five firms recommended that supplier-related items should be removed from the scale of OL because they found it difficult to identify their suppliers and then evaluate supplier-related items. We agreed with the recommendation.

We received assistance from the Zhejiang Province Economic and Information Commission, which is the government department in charge of Zhejiang firms. We obtained a list of firms and randomly selected 485 firms from it to conduct a questionnaire survey. We contacted these firms by e-mail or telephone, introduced the study to them and asked whether they would like to participate in the survey. In total, 250 firms agreed to participate in the survey after two reminders. We then sent questionnaires to these firms primarily by mail. After two reminders, 212 firms returned their completed questionnaires. Of these returned questionnaires, 17 were excluded because the respondents did not meet our criteria, four were excluded because they included incomplete data, and five were excluded due to strong data regularity (e.g., the respondent evaluated most items with the same score). In the end, we obtained 186 valid questionnaires. Table 1 summarizes the characteristics of our sample firms. As shown in Table 1, a diverse sample was constructed in terms of firm size, firm age, and industry type. 
Table 1. Characteristics of participating firms.

\begin{tabular}{|c|c|c|}
\hline Characteristics & Frequency & Percentage $(\%)$ \\
\hline \multicolumn{3}{|c|}{ Sales revenue (RMB million) } \\
\hline 10 or lower & 46 & 24.7 \\
\hline 10-300 & 72 & 38.7 \\
\hline Over 300 & 68 & 36.6 \\
\hline \multicolumn{3}{|c|}{ Firm ages (years) } \\
\hline 10 or younger & 84 & 45.2 \\
\hline $11-20$ & 49 & 26.3 \\
\hline Over 20 & 53 & 28.5 \\
\hline \multicolumn{3}{|c|}{ Industry sector } \\
\hline Manufacturing & 77 & 41.4 \\
\hline Service & 109 & 58.6 \\
\hline \multicolumn{3}{|c|}{ Industry } \\
\hline Electronics and equipment & 25 & 13.4 \\
\hline Chemical and pharmaceutical & 19 & 10.2 \\
\hline Textile and clothing & 18 & 9.7 \\
\hline Food and beverage & 15 & 8.1 \\
\hline Wholesale and retail & 17 & 9.1 \\
\hline Finance & 16 & 8.6 \\
\hline Internet & 46 & 24.7 \\
\hline Information technology & 14 & 7.5 \\
\hline Logistics and distribution & 16 & 8.6 \\
\hline
\end{tabular}

\subsection{Variables and Measures}

We chose the items proposed in the previous literature as the measurement items. We used a 7 -point Likert-type scale $(1=$ strongly disagree to $7=$ strongly agree $)$ when measuring variables.

\subsubsection{BM Innovation}

Although scholars have not given clear answers to the question of how to measure BM innovation, they all emphasized measuring BM innovation from the perspective of changes in lower-order components of BM [14,92]. For example, Von Delft et al. developed a BM innovation scale that focused on measuring changes in customer value proposition, profit formula, key resources, and key processes [14]. Spieth et al. measured the BM innovation as value-offering innovation, value architecture innovation, and revenue model innovation [25].

Findings by Osterwalder and Pigneur have been widely approved and accepted among many studies of BM components [47]. They proposed that BM consists of nine components, including customer segments, value propositions, channels, customer relationships, revenue streams, key resources, key activities, key partnerships, and cost structure; they noted that BMs can be described, visualized, assessed, and changed from the perspective of these nine components. Pedersen et al. developed a $\mathrm{BM}$ innovation scale based on the nine components of Osterwalder and Pigneur and proved that it performs well $[47,92]$. Therefore, BM innovation in this study was measured by using the scale of Pedersen et al. [92] (see Table 2).

\subsubsection{CSR}

CSR comes from the needs of stakeholders such as customers, investors, employees, and society [55]. Although the definitions of CSR are different in the literature, it is generally believed that firms must take actions to meet the expectations of stakeholders [54-56]. Accordingly, scholars argue that CSR should be measured from the perspective of a firm's responses to the general social concerns of stakeholder groups [61,94]. 
Table 2. Reliability and validity.

\begin{tabular}{|c|c|}
\hline Constructs and Items & Loadings \\
\hline \multicolumn{2}{|l|}{ CSR (Cronbach's $\alpha=0.886, \mathrm{CR}=0.897, \mathrm{AVE}=0.594)$} \\
\hline Our company establishes procedures to comply with customer complaints. & 0.720 \\
\hline Our company treats its customers honestly. & 0.759 \\
\hline Our company offers safety at work to its employees. & 0.743 \\
\hline Our company treats its employees fairly (without discrimination or abuses). & 0.742 \\
\hline Our company helps solve social problems. & 0.809 \\
\hline Our company is concerned with improving the general well-being of society. & 0.843 \\
\hline \multicolumn{2}{|l|}{ OL $($ Cronbach's $\alpha=0.884, \mathrm{CR}=0.889, \mathrm{AVE}=0.617)$} \\
\hline Most of the general public would approve of our company if asked their opinion. & 0.859 \\
\hline Most consumers in the general public approve of our company's operating practices. & 0.804 \\
\hline Our company has one of the lowest rates of employee turnover in the industry. & 0.737 \\
\hline Our company follows government regulations for operating procedures in the industry. & 0.862 \\
\hline Our company is committed to meeting the industry standards in its production operations. & 0.645 \\
\hline \multicolumn{2}{|c|}{$\begin{array}{c}\text { BM innovation (Cronbach's } \alpha=0.935, \mathrm{CR}=0.934, \mathrm{AVE}=0.611) \text { (Items complete the sentence "Over } \\
\text { the past three years, } \ldots \text { ") }\end{array}$} \\
\hline Our company's focus is on developing new products and/or services. & 0.765 \\
\hline Our company's focus is on identifying and serving new markets and customer segments. & 0.783 \\
\hline $\begin{array}{l}\text { Our company's focus is on developing and/or acquiring new resources and competences } \\
\text { (technology, people, IT systems, etc.). }\end{array}$ & 0.755 \\
\hline $\begin{array}{c}\text { Our company's focus is on developing new core processes and activities (design, logistics, } \\
\text { marketing, etc.). }\end{array}$ & 0.835 \\
\hline $\begin{array}{l}\text { Our company's focus is on establishing relationships with new strategic business partners } \\
\text { (suppliers, distributors, end users, etc.). }\end{array}$ & 0.829 \\
\hline $\begin{array}{l}\text { Our company's focus is on developing new tools for building customer relationships } \\
\text { (personal service, memberships, bonus systems, etc.). }\end{array}$ & 0.752 \\
\hline $\begin{array}{c}\text { Our company's focus is on selling products and/or services through new channels (own } \\
\text { stores, partner stores, online, etc.). }\end{array}$ & 0.772 \\
\hline $\begin{array}{c}\text { Our company's focus is on making major changes in the combination of costs incurred } \\
\text { when operating the company. }\end{array}$ & 0.784 \\
\hline $\begin{array}{c}\text { Our company has developed new ways of generating revenue (products, services, leasing, } \\
\text { sponsorships, etc.). }\end{array}$ & 0.755 \\
\hline
\end{tabular}

Pérez and Rodríguez del Bosque applied this perspective to develop a CSR image scale to measure customer perception of CSR [59]. In their works, items of measuring CSR were firstly developed through literature review and interviews, and then were modified to items that can be understood and answered by customers. For example, an item "(our company) establishes procedures to comply with customer complaints" adapted from Maignan et al. [95], was firstly developed as one of the items to measure CSR, and then was modified as one of the items to measure CSR image, that is, "I believe that this company establishes procedures to comply with customer complaints".

This paper was concerned with CSR rather than CSR image. Therefore, this paper used CSR items developed by Pérez and Rodríguez del Bosque [59] to measure CSR (see Table 2). In addition, the CSR items developed by them have some advantages. For example, the CSR initiatives in these items have been evaluated by stakeholders (especially customers) as the core initiatives of CSR to meet the expectations of stakeholders; these items can be used not only to measure CSR accurately but also to support design more effective social strategies [59].

\subsubsection{OL}

It is difficult to observe OL because OL is a generalized perception or assumption [36,71]. Therefore, the previous literature has mostly used the case study method. However, some studies have overcome this methodological challenge, arguing that OL can be inferred indirectly through the actions of internal and external audiences [71,96]. The scale developed by Elsbach not only considers internal 
and external endorsement, which is consistent with previous claims of OL measurement, but also considers organizational normativity, which is an attribute that a legitimate organization should have [97]. Therefore, this paper measured OL based on the scale of Elsbach [97] (see Table 2).

\subsubsection{Control variables}

Firm age and firm size have been widely adopted as control variables in previous studies on BM innovation [88-90]. Following these studies, we chose firm age and firm size as control variables because these variables may influence BM innovation. Based on Lyles and Salk [98], we calculated firm age by subtracting the year of firm establishment from the year of our survey. Based on Song et al. [99], we used sales revenue to measure firm size.

\section{Analysis and Results}

\subsection{Nonresponse Bias and Common Method Bias}

To test for nonresponse bias, we examined the differences between respondents and nonrespondents for our sample. T-tests showed no significant differences in terms of sales revenue and firm age. We also used a chi-squared test of dependent variable to compare the early and the late respondents. We defined the first 30 respondents as the early respondents and the last 30 respondents as the late respondents. The result did not reveal any significant differences $(p<0.05)$. To detect common method bias, Harman's single-factor test was conducted [100]. The exploratory factor analysis results for all the variables (i.e., CSR, OL, and BM innovation) show that three distinct factors emerge and explain $67.1 \%$ of the total variance. The first factor explains $28.5 \%$ of the total variance, which is not the majority of total variance. Accordingly, we concluded that common-method bias is not a serious threat.

\subsection{Reliability and Validity}

We performed a confirmatory factor analysis (CFA), using AMOS 24.0, to test the factor structure of the items as well as constructs' reliabilities and validities (see Table 2). The model fit indices were as follows: $\chi^{2} / \mathrm{df}=1.979, \mathrm{RMSEA}=0.073, \mathrm{GFI}=0.862$, AGFI $=0.822, \mathrm{CFI}=0.940, \mathrm{TLI}=0.930$, $\mathrm{IFI}=0.941, \mathrm{NFI}=0.887$. Among these indices, $\chi^{2} / \mathrm{df}$ was less than 3 , and CFI, TLI, and IFI were higher than 0.9, meeting the criteria of a good model fit [101]; RMSEA was less than 0.08, meeting the criteria of a reasonable model fit [101]; GFI and NFI were less than 0.9 but greater than accepted 0.85 thresholds [102]; AGFI, a little less than 0.85, was still within the acceptable range [102]. Overall, these indices suggested the model was acceptable. Factor loadings of all items were above the threshold value of 0.5 (see Table 2), suggesting these items could be retained. We used Cronbach's $\alpha$ and composite reliability to evaluate reliability. From Table 2, it is clear that all values of Cronbach's $\alpha$ and composite reliability were greater than the desired level of 0.7 [103]. We calculated the average variance extracted (AVE) to assess convergent validity. The results show that all values of AVE were greater than the desired level of 0.5 [104]. To determine discriminant validity, the square root of AVE was used. Table 3 shows that the square roots of the AVE values for each construct were greater than the correlations [104]. 
Table 3. Descriptive statistics and correlations between variables.

\begin{tabular}{cccccc}
\hline & $\mathbf{1}$ & $\mathbf{2}$ & $\mathbf{3}$ & $\mathbf{4}$ & $\mathbf{5}$ \\
\hline 1.Firm age & n.a. & & & & \\
2.Firm size & $0.525^{* * *}$ & n.a. & & & \\
3.CSR & $0.229^{* *}$ & $0.198^{* *}$ & 0.771 & & \\
4.OL & 0.110 & $0.127^{* *}$ & $0.767^{* *}$ & 0.785 & \\
5.BM & 0.140 & $0.245^{* *}$ & $0.690^{* * *}$ & $0.663^{* * *}$ & 0.782 \\
innovation & & & 5.533 & 5.202 & 5.264 \\
Mean & 3.330 & 4.450 & 5.145 & 1.096 & 1.120 \\
SD & 2.031 & 2.051 & 1.145
\end{tabular}

Note: The numbers on the diagonal show the square root of AVE. ${ }^{*} p<0.05 .{ }^{* *} p<0.01 .{ }^{* * *} p<0.001$.

\subsection{Hypotheses Testing}

Hierarchical regression analysis method has been widely used to test hypotheses in previous studies on BMs $[4,5,89,90,105]$. Thus, this paper tested the hypotheses using this method. According to Baron and Kenny's methodology [106], the hypothesis testing in this paper included the following processes.

First, we examined the influence of CSR on BM innovation. Model 1 was built to examine the influence of control variables (firm age and size) on BM innovation. Based on model 1, model 2 was built to verify H1. As shown in Table 4, CSR had a significant and positive influence on BM innovation ( $\beta=0.681, p<0.001)$, which indicates that $\mathrm{H} 1$ is supported.

Table 4. Regression results.

\begin{tabular}{ccccccc}
\hline & \multicolumn{7}{c}{ Dependent Variables } \\
\cline { 2 - 7 } & \multicolumn{2}{c}{ BM Innovation } & \multicolumn{2}{c}{ OL } & \multicolumn{2}{c}{ BM Innovation } \\
\hline Model 1 & Model 2 & Model 3 & Model 4 & Model 5 & Model 6 \\
Firm age & 0.015 & -0.102 & 0.060 & -0.074 & -0.024 & -0.078 \\
Firm size & $0.238^{* *}$ & $0.164^{* *}$ & 0.095 & 0.011 & $0.176^{* *}$ & $0.161^{* *}$ \\
CSR & & $0.681^{* * *}$ & & $0.781^{* * *}$ & & $0.428^{* * *}$ \\
OL & & & & & $0.643^{* * *}$ & $0.323^{* * *}$ \\
F & $5.886^{* *}$ & $59.568^{* * *}$ & 1.752 & $88.064^{* * *}$ & $53.034^{* * *}$ & $52.694^{* * *}$ \\
$\mathrm{R}^{2}$ & 0.060 & 0.495 & 0.019 & 0.592 & 0.466 & 0.538 \\
Adjusted $R^{2}$ & 0.050 & 0.487 & 0.008 & 0.585 & 0.458 & 0.528 \\
$\Delta \mathrm{R}^{2}$ & 0.060 & 0.435 & 0.019 & 0.573 & 0.406 & 0.043 \\
\hline
\end{tabular}

Second, we examined the influence of CSR on OL. Model 3 was built to examine the influence of control variables on OL. Model 4 was built based on model 3 to verify H2. As presented in Table 4, CSR significantly and positively influenced OL $(\beta=0.781, p<0.001)$, indicating that $\mathrm{H} 2$ is supported.

Third, we examined the influence of OL on BM innovation. Based on model 1, we built model 5 to check whether $\mathrm{H} 3$ is valid. As shown in Table 4, OL had a significant and positive influence on BM innovation $(\beta=0.643, p<0.001)$. Thus, $\mathrm{H} 3$ is supported.

The above results show that CSR (the independent variable) had a positive influence on BM innovation (the dependent variable), CSR (the independent variable) had a positive influence on OL (the mediating variable), and OL (the mediating variable) had a positive influence on BM innovation (the dependent variable). Therefore, we built model 6 as shown in Table 4 to test whether the mediating effect of OL exists [106]. Comparing model 2 with model 6, we found that the standardized coefficient corresponding to CSR remained significant but fell from 0.681 (model 2) to 0.428 (model 6). This suggests that CSR not only directly influenced BM innovation but also indirectly influenced BM innovation through OL. That is, OL partially mediated the relationship between CSR and BM innovation. Therefore, $\mathrm{H} 4$ is supported. 


\section{Discussion and conclusions}

This paper aimed to explore the influence of CSR on BM innovation through the mediating role of OL. Accordingly, this paper proposed some research hypotheses and used the hierarchical regression analysis method to empirically test them. This paper mainly achieved the following findings. First, our results show that CSR had a positive effect on BM innovation. This finding indicates that CSR is one of the antecedents of BM innovation. Considering that BM innovation is a form of innovation, this finding is consistent with findings of previous studies, which showed that CSR promotes innovation $[55,61,65]$. Thus, firms can use CSR activities to advance their BM innovation. Second, our results show that CSR had a positive effect on OL. This finding is in line with findings of previous studies that showed CSR helps to enhance OL [35,55,78]. According to this finding, firms can use CSR activities to enhance their OL [35,39]. Third, our results show that OL had a positive effect on $\mathrm{BM}$ innovation. Considering that OL is a resource as important as other resources [39], this finding is consistent with findings of previous studies on BM innovation based on RBV [3]. This finding demonstrates that $\mathrm{OL}$ is one of the antecedents of BM innovation, which suggests that firms can link OL to BM innovation. Fourth, our results show that OL partially mediated the relationship between CSR and BM innovation. This finding indicates that CSR not only has a direct influence on BM innovation but also has an indirect influence on BM innovation through the mediating role of OL. Accordingly, firms can make use of both direct and indirect effects of CSR on BM innovation.

\subsection{Theoretical Contributions}

This study makes several theoretical contributions. First, the study illustrates the effect of CSR on purely commercial or for-profit BM innovation. In contrast with previous research that has focused on the influence of CSR on social or sustainable BM innovation [24,27], this study extended to focus on the influence of CSR on purely commercial or for-profit BM innovation. The results show that CSR has a positive effect on purely commercial or for-profit BM innovation.

Second, the study provides a large sample-based empirical evidence for the influence of CSR on BM innovation. The existing research has claimed that CSR has a positive effect on BM innovation, but there is no empirical evidence. This paper conducted a large sample-based empirical study and verifies the influence of CSR on BM innovation.

Third, the study promotes the understanding of the indirect relationship between CSR and BM innovation. The study explored how CSR influences BM innovation by examining the mediating role of OL. The results show that CSR can influence BM innovation through the mediating role of OL, indicating that there is an indirect relationship between CSR and BM innovation.

Fourth, the study adds to the literature exploring the antecedents of BM innovation. In this study, we focused on examining relationships between CSR, OL, and BM innovation. Our results suggest that both CSR and OL can influence BM innovation, demonstrating that they are antecedents of BM innovation. In addition, we explored the relationship between CSR and OL, and the mediating role of OL in the influence of CSR on BM innovation, providing a process mechanism of BM innovation showing that CSR can influence BM innovation through OL.

\subsection{Managerial Implications}

This study provides some practical implications for managers as well. First, firms can play the role of CSR in BM innovation and further improve their financial performance. Firms are cautious or even skeptical about CSR investment due to the debate over the relationship between CSR and financial performance. The findings of this paper provide an effective way for CSR investment to improve financial performance. Considering the positive effect of BM innovation on financial performance, firms should link CSR investment to BM innovation and in turn improve their financial performance. Specifically, firms can increase the social attributes of their products or services and value creation systems to improve their existing BMs, or implement CSR-based business strategies to build completely 
new BMs. Second, firms can gain competitive advantage brought about by BM innovation by linking CSR to OL. Firms can increase CSR investment and engage in CSR activities to establish, maintain, and enhance legitimacy, and then give full play to the role of legitimacy in acquiring and allocating organizational external resources. Accordingly, firms can integrate their external and internal resources, which help to increase their resource base and heterogeneity, thus providing the possibility of realizing heterogeneous BM innovation at lower cost, and finally providing opportunities for firms to gain competitive advantage through BMI innovation.

\subsection{Limitations and Future Research}

This study has several limitations that should be addressed in future research. First, it did not explore the contingency factors of CSR influencing BM innovation through OL. Future research can introduce some moderator variables into the research model, such as environmental dynamics and resource integration capabilities, to examine the impact of these variables on the relationship among CSR, OL, and BM innovation. Second, this study did not explore internal factors through which CSR could influence BM innovation. CSR enables some internal factors of the organization, such as CEO risk-taking incentives [68]. Future research can introduce these internal factors as mediating variables to increase the understanding of how CSR influences BM innovation. Third, this study used questionnaire survey to collect data. Although this approach has been adopted by many scholars especially in the BM field, it may also lead to measurement bias. Future research can address this limitation by using different data collection approaches (e.g., obtaining objective data from third parties). Fourth, problems of endogeneity were not discussed in this study. Following empirical studies based on survey in the field of CSR $[53,57]$ and BM $[4,5]$, this study did not take into account the endogenous problem in regression analysis. Future research should explore endogeneity to reduce the impact of endogeneity $[107,108]$.

Author Contributions: Conceptualization, B.H. and T.Z.; methodology, B.H.; software, S.Y.; validation, B.H., T.Z. and S.Y.; formal analysis, B.H.; investigation, T.Z. and S.Y.; resources, B.H. and S.Y.; data curation, T.Z.; writing-original draft preparation, B.H., S.Y., and T.Z.; writing-review and editing, T.Z.; visualization, T.Z.; supervision, B.H.; project administration, B.H. and T.Z.; funding acquisition, B.H. and T.Z. All authors have read and agreed to the published version of the manuscript.

Funding: This research was funded by the National Social Science Fund of China (grant number 18BGL025), the Fundamental Research Funds for the Provincial Universities of Zhejiang (grant number GK199900299012-202), and Macau Foundation (grant number MF1928).

Conflicts of Interest: The authors declare no conflict of interest.

\section{References}

1. Zott, C.; Amit, R.; Massa, L. The business model: Recent developments and future research. J. Manag. 2011, 37, 1019-1042.

2. Zott, C.; Amit, R. Business model design: An activity system perspective. Long Range Plan. 2010, 43, $216-226$. [CrossRef]

3. George, G.; Bock, A.J. The business model in practice and its implications for entrepreneurship research. Entrep. Theory Pract. 2011, 35, 83-111. [CrossRef]

4. Brettel, M.; Strese, S.; Flatten, T.C. Improving the performance of business models with relationship marketing efforts-An entrepreneurial perspective. Eur. Manag. J. 2012, 30, 85-98. [CrossRef]

5. Pati, R.K.; Nandakumar, M.K.; Ghobadian, A.; Ireland, R.D.; O'Regane, N. Business model design-performance relationship under external and internal contingencies: Evidence from SMEs in an emerging economy. Long Range Plan. 2018, 51, 750-769. [CrossRef]

6. Teece, D.J. Business models, business strategy and innovation. Long Range Plan. 2010, 43, 172-194. [CrossRef]

7. Ricciardi, F.; Zardini, A.; Rossignoli, C. Organizational dynamism and adaptive business model innovation: The triple paradox configuration. J. Bus. Res. 2016, 69, 5487-5493. [CrossRef]

8. Saebi, T.; Lien, L.; Foss, N.J. What drives business model adaptation? The impact of opportunities, threats and strategic orientation. Long Range Plan. 2017, 50, 567-581. [CrossRef] 
9. Achtenhagen, L.; Melin, L.; Naldi, L. Dynamics of business models—Strategizing, critical capabilities and activities for sustained value creation. Long Range Plan. 2013, 46, 427-442. [CrossRef]

10. Chesbrough, H. Business model innovation: It's not just about technology anymore. Strateg. Leadersh. 2007, 35, 12-17. [CrossRef]

11. Foss, N.J.; Saebi, T. Fifteen years of research on business model innovation: How far have we come, and where should we go? J. Manag. 2017, 43, 200-227. [CrossRef]

12. Andries, P.; Debackere, K. Business model innovation: Propositions on the appropriateness of different learning approaches. Creat. Innov. Manag. 2013, 22, 337-358. [CrossRef]

13. Frankenberger, K.; Sauer, R. Cognitive antecedents of business models: Exploring the link between attention and business model design over time. Long Range Plan. 2019, 52, 283-304. [CrossRef]

14. von Delft, S.; Kortmann, S.; Gelhard, C.; Pisani, N. Leveraging global sources of knowledge for business model innovation. Long Range Plan. 2019, 52, 1-20. [CrossRef]

15. Sosna, M.; Trevinyo-Rodríguez, R.N.; Velamuri, S.R. Business model innovation through trial-and-error learning: The Naturhouse case. Long Range Plan. 2010, 43, 383-407. [CrossRef]

16. Teece, D.J. Business models and dynamic capabilities. Long Range Plan. 2018, 51, 40-49. [CrossRef]

17. Aspara, J.; Lamberg, J.-A.; Laukia, A.; Tikkanen, H. Corporate business model transformation and inter-organizational cognition: The case of Nokia. Long Range Plan. 2013, 46, 459-474. [CrossRef]

18. Karimi, J.; Walter, Z. Corporate entrepreneurship, disruptive business model innovation adoption, and its performance: The case of the newspaper industry. Long Range Plan. 2016, 49, 342-360. [CrossRef]

19. Ferreira, F.N.H.; Proença, J.F.; Spencer, R.; Cova, B. The transition from products to solutions: External business model fit and dynamics. Ind. Mark. Manag. 2013, 42, 1093-1101. [CrossRef]

20. Miller, K.; McAdam, M.; McAdam, R. The changing university business model: A stakeholder perspective. RD Manag. 2014, 44, 265-287. [CrossRef]

21. Fleury, A.; Fleuryand, M.T.L. Local enablers of business models: The experience of Brazilian multinationals acquiring in North America. J. Bus. Res. 2014, 67, 516-526. [CrossRef]

22. Lee, I.; Lee, K. The internet of things (IoT): Applications, investments, and challenges for enterprises. Bus. Horiz. 2015, 58, 431-440. [CrossRef]

23. Foss, N.J.; Saebi, T. Business models and business model innovation: Between wicked and paradigmatic problems. Long Range Plan. 2018, 51, 9-21. [CrossRef]

24. Olofsson, S.; Hoveskog, M.; Halila, F. Journey and impact of business model innovation: The case of a social enterprise in the Scandinavian electricity retail market. J. Clean. Prod. 2018, 175, 70-81. [CrossRef]

25. Spieth, P.; Schneider, S.; Clauß, T.; Eichenberg, D. Value drivers of social businesses: A business model perspective. Long Range Plan. 2019, 52, 427-444. [CrossRef]

26. Yunus, M.; Moingeon, B.; Lehmann-Ortega, L. Building social business models: Lessons from the Grameen experience. Long Range Plan. 2010, 43, 308-325. [CrossRef]

27. Dembek, K.; York, J.; Singh, P.J. Creating value for multiple stakeholders: Sustainable business models at the base of the pyramid. J. Clean. Prod. 2018, 196, 1600-1612. [CrossRef]

28. Geissdoerfer, M.; Vladimirova, D.; Evans, S. Sustainable business model innovation: A review. J. Clean. Prod. 2018, 198, 401-416. [CrossRef]

29. Rotondo, F.; Corsi, K.; Giovanelli, L. The social side of sustainable business models: An explorative analysis of the low-cost airline industry. J. Clean. Prod. 2019, 225, 806-819. [CrossRef]

30. Slack, K. Mission impossible: Adopting a CSR-based business model for extractive industries in developing countries. Resour. Policy 2012, 37, 179-184. [CrossRef]

31. Dentchev, N.; Baumgartner, R.; Dieleman, H.; Jóhannsdóttir, L.; Jonker, J.; Nyberg, T.; Rauter, R.; Rosano, M.; Snihur, Y.; Tang, X.; et al. Embracing the variety of sustainable business models: Social entrepreneurship, corporate intrapreneurship, creativity, innovation, and other approaches to sustainability challenges. J. Clean. Prod. 2016, 113, 1-4. [CrossRef]

32. Czinkota, M.; Kaufmann, H.R.; Basile, G.; Ferri, M.A. For-Benefit company (fBComp): An innovative social-business model. The Italian case. J. Bus. Res. 2018, in press. [CrossRef]

33. Magretta, J. Why business models matter. Harv. Bus. Rev. 2002, 80, 86-92. [PubMed]

34. Wang, Z.; Sarkis, J. Corporate social responsibility governance, outcomes, and financial performance. J. Clean. Prod. 2017, 162, 1607-1616. [CrossRef] 
35. Zheng, Q.; Luo, Y.; Maksimov, V. Achieving legitimacy through corporate social responsibility: The case of emerging economy firms. J. World Bus. 2015, 50, 389-403. [CrossRef]

36. Suchman, M.C. Managing legitimacy: Strategic and institutional approaches. Acad. Manag. Rev. 1995, 20, 571-610. [CrossRef]

37. Zimmerman, M.A.; Zeitz, G.J. Beyond survival: Achieving new venture growth by building legitimacy. Acad. Manag. Rev. 2002, 27, 414-431. [CrossRef]

38. Colleoni, E. CSR communication strategies for organizational legitimacy in social media. Corp. Commun. Int. J. 2013, 18, 228-248. [CrossRef]

39. Markard, J.; Wirth, S.; Truffer, B. Institutional dynamics and technology legitimacy-A framework and a case study on biogas technology. Res. Policy 2016, 45, 330-344. [CrossRef]

40. Casadesus-Masanell, R.; Ricart, J.E. From strategy to business models and onto tactics. Long Range Plan. 2010, 43, 195-215. [CrossRef]

41. Desyllas, P.; Sako, M. Profiting from business model innovation: Evidence from pay-as-you-drive auto insurance. Res. Policy 2013, 42, 101-116. [CrossRef]

42. Dmitriev, V.; Simmons, G.; Truong, Y.; Palmer, M.; Schneckenberg, D. An exploration of business model development in the commercialization of technology innovations. RD Manag. 2014, 44, 306-321. [CrossRef]

43. Dahan, N.M.; Doh, J.P.; Oetzel, J.; Yaziji, M. Corporate-NGO collaboration: Co-Creating new business models for developing markets. Long Range Plan. 2010, 43, 326-342. [CrossRef]

44. Baden-Fuller, C.; Haefliger, S. Business models and technological innovation. Long Range Plan. 2013, 46, 419-426. [CrossRef]

45. Ghezzi, A.; Cortimiglia, M.N.; Frank, A.G. Strategy and business model design in dynamic telecommunications industries: A study on Italian mobile network operators. Technol. Forecast. Soc. Chang. 2015, 90, 346-354. [CrossRef]

46. Shafer, S.M.; Smith, H.J.; Linder, J.C. The power of business models. Bus. Horiz. 2005, 48, 199-207. [CrossRef]

47. Osterwalder, A.; Pigneur, Y. Business Model Generation: A Handbook for Visionaries, Game Changers, and Challengers; John Wiley \& Sons: Somerset, NJ, USA, 2010.

48. Casadesus-Masanell, R.; Zhu, F. Business model innovation and competitive imitation: The case of sponsor-based business models. Strateg. Manag. J. 2013, 34, 464-482. [CrossRef]

49. Mitchell, D.; Coles, C. The ultimate competitive advantage of continuing business model innovation. J. Bus. Strateg. 2003, 24, 15-21. [CrossRef]

50. Khanagha, S.; Volberda, H.; Oshri, I. Business model renewal and ambidexterity: Structural alteration and strategy formation process during transition to a Cloud business model. RD Manag. 2014, 44, 322-340. [CrossRef]

51. Becchetti, L.; Ciciretti, R.; Hasan, I.; Kobeissi, N. Corporate social responsibility and shareholder's value. J. Bus. Res. 2012, 65, 1628-1635. [CrossRef]

52. Bhardwaj, P.; Chatterjee, P.; Demir, K.D.; Turut, O. When and how is corporate social responsibility profitable? J. Bus. Res. 2018, 84, 206-219. [CrossRef]

53. Baskentli, S.; Sen, S.; Du, S.; Bhattacharya, C.B. Consumer reactions to corporate social responsibility: The role of CSR domains. J. Bus. Res. 2019, 95, 502-513. [CrossRef]

54. Carroll, A.B. A three-dimensional conceptual model of corporate performance. Acad. Manag. Rev. 1979, 4, 497-505. [CrossRef]

55. McWilliams, A.; Siegel, D. Corporate social responsibility: A theory of the firm perspective. Acad. Manag. Rev. 2001, 26, 117-127. [CrossRef]

56. Van Marrewijk, M. Concepts and definitions of CSR and corporate sustainability: Between agency and communion. J. Bus. Ethics 2003, 44, 95-105. [CrossRef]

57. Jeong, H.J.; Paek, H.J.; Lee, M. Corporate social responsibility effects on social network sites. J. Bus. Res. 2013, 66, 1889-1895. [CrossRef]

58. Park, B.I.; Chidlow, A.; Choi, J. Corporate social responsibility: Stakeholders influence on MNEs' activities. Int. Bus. Rev. 2014, 23, 966-980. [CrossRef]

59. Pérez, A.; Rodríguez del Bosque, I. Measuring CSR image: Three studies to develop and to validate a reliable measurement tool. J. Bus. Ethics 2013, 118, 265-286. [CrossRef]

60. Lau, A.K.; Lee, P.K.; Cheng, T. An empirical taxonomy of corporate social responsibility in China's manufacturing industries. J. Clean. Prod. 2018, 188, 322-338. [CrossRef] 
61. Martinez-Conesa, I.; Soto-Acosta, P.; Palacios-Manzano, M. Corporate social responsibility and its effect on innovation and firm performance: An empirical research in SMEs. J. Clean. Prod. 2017, 142, 2374-2383. [CrossRef]

62. Xie, X.; Jia, Y.; Meng, X.; Li, C. Corporate social responsibility, customer satisfaction, and financial performance: The moderating effect of the institutional environment in two transition economies. J. Clean. Prod. 2017, 150, 26-39. [CrossRef]

63. Boons, F.; Lüdeke-Freund, F. Business models for sustainable innovation: State-of-the-Art and steps towards a research agenda. J. Clean. Prod. 2013, 45, 9-19. [CrossRef]

64. Kim, H.L.; Rhou, Y.; Uysal, M.; Kwon, N. An examination of the links between corporate social responsibility (CSR) and its internal consequences. Int. J. Hosp. Manag. 2017, 61, 26-34. [CrossRef]

65. Halkos, G.; Skouloudis, A. Corporate social responsibility and innovative capacity: Intersection in a macro-level perspective. J. Clean. Prod. 2018, 182, 291-300. [CrossRef]

66. Boons, F.; Montalvo, C.; Quist, J.; Wagner, M. Sustainable innovation, business models and economic performance: An overview. J. Clean. Prod. 2013, 45, 1-8. [CrossRef]

67. Patzelt, H.; Zu Knyphausen-Aufseß, D.; Nikol, P. Top management teams, business models, and performance of biotechnology ventures: An upper echelon perspective. Br. J. Manag. 2008, 19, 205-221. [CrossRef]

68. Dunbar, C.G.; Li, Z.F.; Shi, Y. Corporate social responsibility and CEO risk-taking incentives. SSRN Electron. J. 2017, 40. [CrossRef]

69. Lee, Y.-J.; Yoon, H.J.; O’Donnell, N.H. The effects of information cues on perceived legitimacy of companies that promote corporate social responsibility initiatives on social networking sites. J. Bus. Res. 2018, 83, 202-214. [CrossRef]

70. Pollock, T.G.; Rindova, V.P. Media legitimation effects in the market for initial public offerings. Acad. Manag. J. 2003, 46, 631-642.

71. Tornikoski, E.T.; Newbert, S.L. Exploring the determinants of organizational emergence: A legitimacy perspective. J. Bus. Ventur. 2007, 22, 311-335. [CrossRef]

72. Czinkota, M.; Kaufmann, H.R.; Basile, G. The relationship between legitimacy, reputation, sustainability and branding for companies and their supply chains. Ind. Mark. Manag. 2014, 43, 91-101. [CrossRef]

73. Zhang, H.; Young, M.N.; Tan, J.; Sun, W. How Chinese companies deal with a legitimacy imbalance when acquiring firms from developed economies. J. World Bus. 2018, 53, 752-767. [CrossRef]

74. Bachmann, P.; Ingenhoff, D. Legitimacy through CSR disclosures? The advantage outweighs the disadvantages. Public Relat. Rev. 2016, 42, 386-394. [CrossRef]

75. Farache, F.; Perks, K.J. CSR advertisements: A legitimacy tool? Corp. Commun. Int. J. 2010, 15, $235-248$. [CrossRef]

76. Zhao, M. CSR-Based political legitimacy strategy: Managing the state by doing good in China and Russia. J. Bus. Ethics 2012, 111, 439-460. [CrossRef]

77. Grougiou, V.; Dedoulis, E.; Leventis, S. Corporate social responsibility reporting and organizational stigma: The case of "sin" industries. J. Bus. Res. 2016, 69, 905-914. [CrossRef]

78. Roeck, K.; Delobbe, N. Do environmental CSR initiatives serve organizations' legitimacy in the oil industry? Exploring employees' reactions through organizational identification theory. J. Bus. Ethics 2012, 110, 397-412. [CrossRef]

79. Dopfer, M.; Fallahi, S.; Kirchberger, M.; Gassmann, O. Adapt and strive:how ventures under resource constraints create value through business model adaptations. Creat. Innov. Manag. 2017, 26, 233-246. [CrossRef]

80. Johnson, M.W.; Christensen, C.M.; Kagermann, H. Reinventing your business model. Harv. Bus. Rev. 2008, 86, 50-59.

81. Hamel, G. Bringing Silicon valley inside. Harv. Bus. Rev. 1999, 77, 70-84.

82. Berglund, H.; Sandström, C. Business model innovation from an open systems perspective: Structural challenges and managerial solutions. Int. J. Prod. Dev. 2013, 18, 274-285. [CrossRef]

83. Kwak, J.; Zhang, Y.; Yu, J. Legitimacy building and e-commerce platform development in China: The experience of Alibaba. Technol. Forecast. Soc. Chang. 2019, 139, 115-124. [CrossRef] 
84. Park, H.-S.; Auh, S.; Maher, A.A.; Singhapakdi, A. Marketing's accountability and internal legitimacy: Implications for firm performance. J. Bus. Res. 2012, 65, 1576-1582. [CrossRef]

85. Saeidi, S.P.; Sofian, S.; Saeidi, P.; Saeidi, S.P.; Saeidi, A.S. How does corporate social responsibility contribute to firm financial performance? The mediating role of competitive advantage, reputation, and customer satisfaction. J. Bus. Res. 2015, 68, 341-350. [CrossRef]

86. Bai, X.; Chang, J.; Li, J.J. How do international joint ventures build legitimacy effectively in emerging economies? CSR, political ties, or both? Manag. Int. Rev. 2019, 59, 387-412. [CrossRef]

87. Ma, H.; Guo, H.; Shen, R. Organisational regulatory legitimacy, entrepreneurial orientation, and SME innovation: An optimal distinctiveness perspective. Technol. Anal. Strateg. Manag. 2019, 31, 833-847. [CrossRef]

88. Wei, Z.; Song, X.; Wang, D. Manufacturing flexibility, business model design, and firm performance. Int. J. Prod. Econ. 2017, 193, 87-97. [CrossRef]

89. Yu, C.; Zhang, Z.; Liu, Y. Understanding new ventures' business model design in the digital era: An empirical study in China. Comput. Hum. Behav. 2019, 95, 238-251. [CrossRef]

90. Zott, C.; Amit, R. The fit between product market strategy and business model: Implications for firm performance. Strateg. Manag. J. 2008, 29, 1-26. [CrossRef]

91. Lloréns Montes, F.J.; Ruiz Moreno, A.; García Morales, V. Influence of support leadership and teamwork cohesion on organizational learning, innovation and performance: An empirical examination. Technovation 2005, 25, 1159-1172. [CrossRef]

92. Pedersen, E.R.G.; Gwozdz, W.; Hvass, K.K. Exploring the relationship between business model innovation, corporate sustainability, and organisational values within the fashion industry. J. Bus. Ethics 2018, 149, 267-284. [CrossRef]

93. March, J.G. Exploration and exploitation in organizational learning. Organ. Sci. 1991, 2, 71-87. [CrossRef]

94. Fatma, M.; Rahman, Z.; Khan, I. Multi-Item stakeholder based scale to measure CSR in the banking industry. Int. Strateg. Manag. Rev. 2014, 2, 9-20. [CrossRef]

95. Maignan, I.; Ferrell, O.C.; Hult, G.T.M. Corporate citizenship: Cultural antecedents and business benefits. J. Acad. Mark. Sci. 1999, 27, 455-469. [CrossRef]

96. Certo, S.T.; Hodge, F. Top management team prestige and organizational legitimacy: An examination of investor perceptions. J. Manag. Issues 2007, 19, 461-477.

97. Elsbach, K.D. Managing organizational legitimacy in the California cattle industry: The construction and effectiveness of verbal accounts. Adm. Sci. Q. 1994, 39, 57-88. [CrossRef]

98. Lyles, M.A.; Salk, J.E. Knowledge acquisition from foreign parents in international joint ventures: An empirical examination in the Hungarian context. J. Int. Bus. Stud. 1996, 27, 877-903. [CrossRef]

99. Song, M.; Van Der Bij, H.; Weggeman, M. Determinants of the level of knowledge application: A knowledge-based and information-processing perspective. J. Prod. Innov. Manag. 2005, 22, 430-444. [CrossRef]

100. Podsakoff, P.M.; MacKenzie, S.B.; Lee, J.-Y.; Podsakoff, N.P. Common method biases in behavioral research: A critical review of the literature and recommended remedies. J. Appl. Psychol. 2003, 88, 879-903. [CrossRef]

101. Baumgartner, H.; Homburg, C. Applications of structural equation modeling in marketing and consumer research: A review. Int. J. Res. Mark. 1996, 13, 139-161. [CrossRef]

102. Hinkin, T.R. A review of scale development practices in the study of organizations. J. Manag. 1995, 21, 967-988. [CrossRef]

103. Nunnally, J.C. Psychometric Theory; McGraw-Hill: New York, NY, USA, 1978.

104. Fornell, C.; Larcker, D.F. Evaluating structural equation models with unobservable variables and measurement error. J. Mark. Res. 1981, 18, 39-50. [CrossRef]

105. Zott, C.; Amit, R. Business model design and the performance of entrepreneurial firms. Organ. Sci. 2007, 18, 181-199. [CrossRef]

106. Baron, R.M.; Kenny, D.A. The moderator-mediator variable distinction in social psychological research: Conceptual, strategic, and statistical considerations. J. Personal. Soc. Psychol. 1986, 51, 1173-1182. [CrossRef] 
107. Cole, J.L.; Li, Z.F. An empirical assessment of empirical corporate finance. SSRN Electron. J. $2019,111$. [CrossRef]

108. Cole, J.L.; Li, Z.F. Managerial attributes, incentives, and performance. SSRN Electron. J. 2019, 64. [CrossRef]

(C) 2020 by the authors. Licensee MDPI, Basel, Switzerland. This article is an open access article distributed under the terms and conditions of the Creative Commons Attribution (CC BY) license (http://creativecommons.org/licenses/by/4.0/). 